\title{
Human nail stem cells are retained but hypofunctional during aging
}

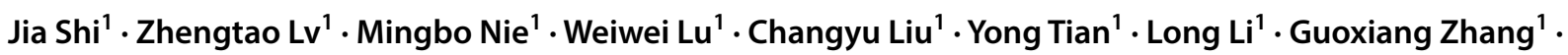 \\ Ranyue Ren ${ }^{1} \cdot$ Ziyang Zhang $^{1} \cdot$ Hao Kang ${ }^{1}$
}

Received: 2 February 2018 / Accepted: 26 March 2018 / Published online: 9 April 2018

(c) The Author(s) 2018

\begin{abstract}
The nail is a continuous skin appendage. Cells located around the nails, which display coordinated homeostatic dynamics and release a flow of stem cells in response to regeneration, have been identified in mice. However, very few studies regarding human nail stem cells exist in the literature. Using specimens isolated from humans, we detected an unreported population of cells within the basal layer of postnatal human nail proximal folds (NPFs) and the nail matrix around the nail root. These cells were multi-expressing and expressed stem cell markers, such as keratin 15 (K15), keratin 14 (K14), keratin 19 (K19), $\mathrm{CD} 29, \mathrm{CD} 34$, and leucine-rich repeat-containing G protein-coupled receptor 6 (Lgr6). These cells were very similar to mouse nail stem cells in terms of cell marker expression and their location within the nail. We also found that the putative nail stem cells maintained their abundance with advancing age, but cell proliferation and nail growth rate were decreased on comparison of young and aged specimens. To summarize, we found a putative population of stem cells in postnatal human nails located at NPFs and the nail matrix. These cells may have potential for cell differentiation and be capable of responding to injury, and were retained, but may be hypofunctional during aging.
\end{abstract}

Keywords Human nail $\cdot$ Stem cell $\cdot$ Aging $\cdot$ Regeneration

\section{Introduction}

The nail is the largest and most complex appendage of the skin in the human body. Skin, constituting the largest organ in our body, functions to defend against external threats, excrete waste from the body, and maintain body temperature (Johansen 2017). Skin and its appendages are in a process of permanent regeneration. Epidermal resident

Ziyang Zhang

zhangziyang776@gmail.com

Hao Kang

kanghao100@vip.sina.com

Jia Shi

1990sj1025@163.com

Zhengtao Lv

630105736@qq.com

Mingbo Nie

64425770@qq.com

Weiwei Lu

215285906@qq.com

Changyu Liu

liuchangyutj@163.com stem cells are found in the outermost layer of mammalian skin. These stem cells are responsible for continuous self-renewal, which sustains tissue homeostasis. There is a point in skin turnover where epidermal cells are found in the basal cell layer, forming epidermal proliferative units (Mackenzie 1970, 1997). Li et al. isolated and purified epidermal stem cells from neonatal foreskin through enzymatic digestion and identified specific epidermal stem cell
Yong Tian

15972969220@163.com

Long Li

longleev@126.com

Guoxiang Zhang

1334011747@qq.com

Ranyue Ren

245383603@qq.com

1 Department of Orthopedics, Tongji Hospital, Tongji Medical College, Huazhong University of Science and Technology, 1095 Jiefang Avenue, Qiaokou District, Wuhan 430030, China 
markers (Jones and Watt 1993; Li et al. 1998). For skin to function, all components, including hair, sweat glands, sebaceous glands, and nails, must contribute. Several previous studies have evaluated and identified different types of skin stem cells (Cotsarelis 2006; Danner et al. 2012; Leung et al. 2013; Lyle et al. 1998; Trempus et al. 2003; Zhu et al. 2014). One stem cell type is that of hair follicle stem cells; they reside in bulge regions, are multi-potent (Oshima et al. 2001), and can differentiate into non-epithelial cells, such as neurons and adipocytes (Toma et al. 2001). Sweat gland-derived stem cells are also multipotent (Egana et al. 2009). However, there has been little previous research on human nail stem cells.

Human nails are located in the dorsal region of the fingertip and have a protective function (Haneke 2015). Nails begin to form during the ninth week of the embryo's life and develop a visible nail plate after 5 weeks (Haneke 2015). The nail itself belongs to differentiated tissue (Zaias 1963). A nail unit consists of four components: the nail matrix, nail bed, nail plate, and nail fold (Haneke 2014, 2015) (Fig. 1a). The nail fold is the area of the epithelial fold close to the proximal nail bed, and the NPFs and nail matrix are locations where previous studies have identified stem cells in mice (Lehoczky and Tabin 2015; Leung et al. 2014; Nakamura and Ishikawa 2008). However, to date, there has been little research into postnatal human nail stem cells. Stem cells, which differentiate and contribute to the formation of the nail structure and peri-nail epidermis, have previously been found around the nails in rodents (Lehoczky and Tabin 2015; Leung et al. 2014). For example, Leung et al. found bifunctional stem cells around the nails in mice (Leung et al. 2014). If the same or analogous cells are found in human nails, we may be closer to realising the regeneration of much larger areas of limbs and even the regrowth of whole limbs and other non-regenerating tissues. Previous studies have found that the digit tip blastema consists of different species of progenitor cells (Rinkevich et al. 2011). In human fingertips, only the nail can regenerate after amputation; indeed, it is necessary for the regeneration of the fingertip (Neufeld and Zhao 1995). Takeo et al. 2013 showed that nails contribute to digit tip regeneration at the molecular level. Meanwhile, through rigorous measurements and calculation, we observed that young and aged people have different nail growth rates. However, whether this is related to nail stem cells remains to be confirmed.

In this study, we searched for putative stem cells in human nails to identify their specific locations and to determine any difference in the number and/or function of those cells and their locations during aging. This study was conducted in light of recent discoveries that stem cells around mouse nails were required for digit tip regeneration (Lehoczky and Tabin 2015; Leung et al. 2014). Therefore, identifying human nail stem cells and their regenerative potential may help provide new therapies for patients with defects of the digits, as well as amputees.

\section{Materials and methods}

\section{Specimens and slice production}

All samples used in this study were obtained postnatally from humans. Samples were collected from September 2015 to June 2017. In total, 61 participants were recruited initially, with 58 finally completing the protocol (Table 1). All participants gave written informed consent, and the study was approved by the Ethics Committee at Huazhong University of Science and Technology. We first collected distal finger segments from the study participants, most of whom were children with polydactyly, adults with trauma leading to amputation, or patients with other medical conditions requiring amputation. Due to the slice limitation for the tissues, we removed the nail plate and distal phalanx, leaving only the nail bed and the surrounding soft tissues for paraffin and frozen sections.

\section{Immunohistochemistry and immunofluorescence staining}

For all stains, specimens were fixed in $4 \%$ [vol/ $/ \mathrm{vol}$ in phosphate-buffered saline (PBS)] paraformaldehyde. Tissue sections were stained with hematoxylin and eosin (H\&E) for visualisation. For immunofluorescence staining, the tissue was cut into $4-\mu \mathrm{m}$ cryosections, and the putative nail stem cells were plated onto a 96-well plate and incubated with the following primary antibodies: K14 (1:200; Abcam, Cambridge, UK, ab7800), K15 (1:200; Thermo Fisher Scientific, Waltham, MA, USA, MA5-11344), K15 (1:100; Proteintech Group, 10137-1-AP), K19 (1:200; Abcam, ab52625), CD34 (1:100; BOSTER, Wuhan, China, BA0532), CD29 (1:200; Abcam, ab52971), Lgr6 (1:100; Abcam, ab126747), and Ki67 (1:100; BOSTER, PB0065). The cells were then incubated with the following secondary antibodies: goat antirabbit FITC 1:100 (BOSTER, BA1090) and goat anti-mouse TRITC 1:100 (BOSTER, BA1089). DAPI (Thermo Fisher Scientific, D3571) staining was used to display the nuclei. For immunohistochemistry staining, the tissue was cut into $3-\mu \mathrm{m}$ paraffin sections. Paraffin sections of human nail samples were analysed using the IHC kit (BOSTER, SA1022).

\section{Isolation of nail stem cells and clonogenicity assays}

Human nail stem cells were isolated according to the method previously described by Leung et al. (2014). Briefly, the fingers were collected and the epidermis was carefully cut open at the proximal fold to reveal the nail stem cells. Next, 
a
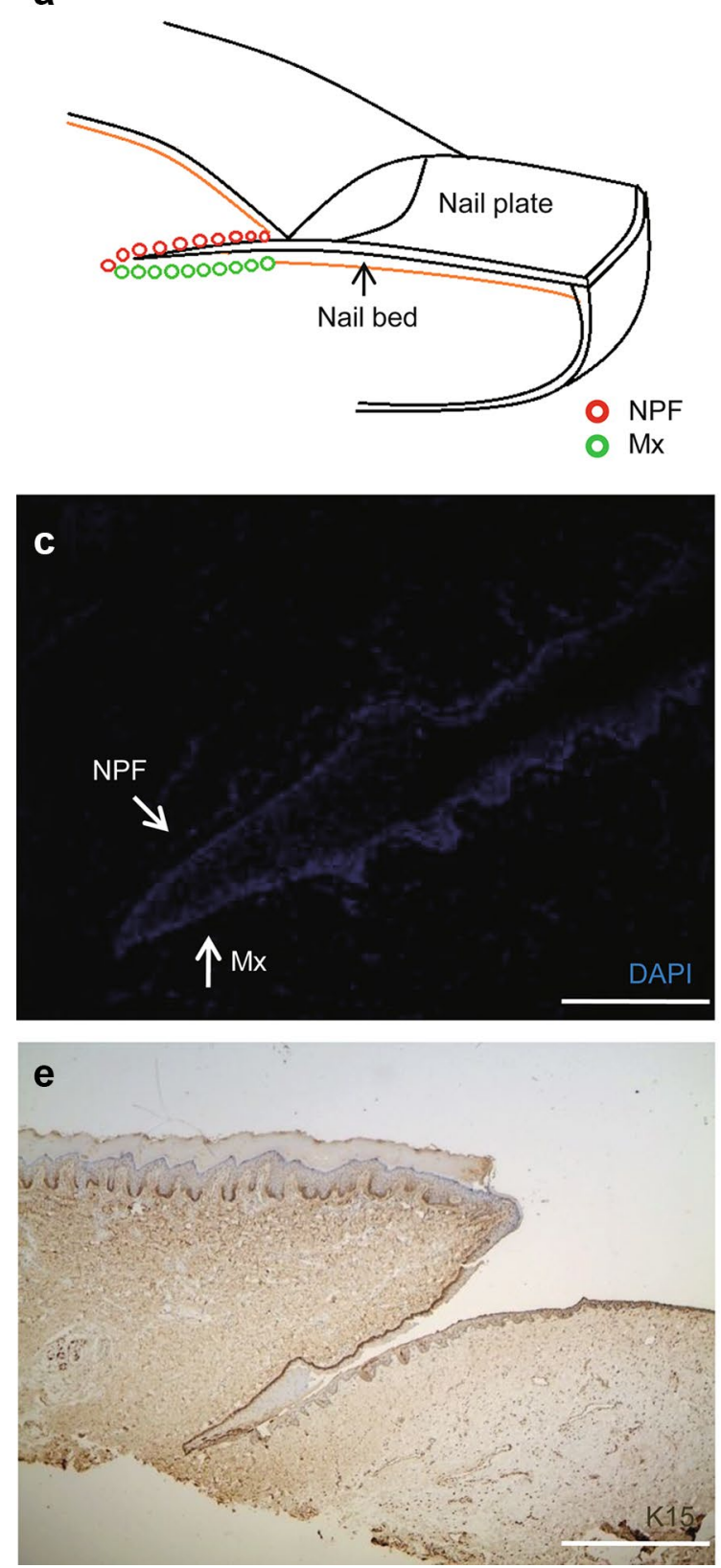

Fig. 1 Localisation of stem cells in human nails. Side view, components of the human nail a Red circles are cells in nail proximal folds (NPFs); green circles are cells in the nail matrix (Mx). We found $\mathrm{K} 5^{+}$label-retaining cells in human nails in both the NPF and Mx. The diagrammatic drawing shows the tangent plane of the slice. b H\&E staining of human nail side facing showing the nail bed (NB), nail root at the Mx and the NPF junction (scale bar

strips of nail stem cells were individually isolated through microdissection and collected in PBS. Next, the isolated strips were digested with $0.25 \%$ trypsin-EDTA overnight at $4{ }^{\circ} \mathrm{C}$ with shaking. Single cells were filtered through a $40-\mu \mathrm{m}$ cell strainer and cultured in Defined KeratinocyteSFM (DKSFM, Thermo Fisher Scientific, 10744019). The
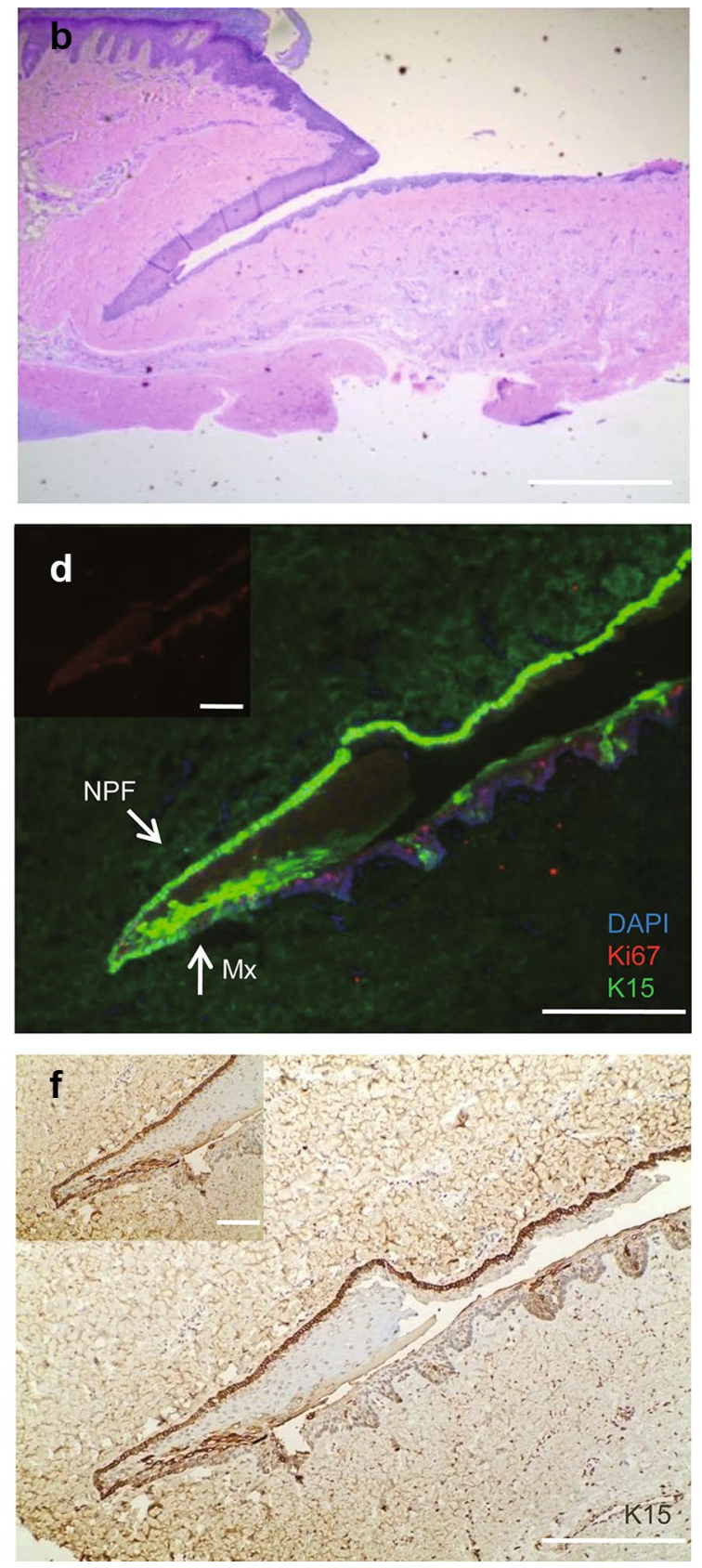

$=1000 \mu \mathrm{m})$. c, $\mathbf{d}$ Immunofluorescence staining for K15 (green) and Ki67 (red); cell nuclei were stained blue by DAPI, image of separately staining of Ki67 in the upper left corner. The positive expression of $\mathrm{K} 15$ extended from the PF to the proximal Mx (scale bar $=200 \mu \mathrm{m}$ ). e Immumohistochemical staining for K15 (brown) (scale bar $=1000 \mu \mathrm{m}$ ). f Magnified photographs of immumohistochemical staining for K15 (brown) (scale bar $=200 \mu \mathrm{m})$. (Color figure online)

culture medium was changed every 3 days. Next, cells were plated onto a 24-well plate, and cell growth was examined and counted daily. For colony growth, equal initial seeding numbers of $\mathrm{K}^{+} 5^{+}$cells were plated in 12 -well plate with $0.3 \mathrm{mM}$ calcium and $15 \%$ (vol/vol) serum (Nowak and Fuchs 2009), in triplicate. After 2 weeks in culture, cells were fixed 
in $10 \%$ formalin and stained with crystal violet. Colonies numbers were counted and measured by using Image $\mathrm{J}$.

\section{Quantification of cell metabolic activity}

A Cell Counting Kit-8 (CCK8) (BOSTER, AR1160) was used to test the proliferative abilities of the cells. Nail stem cells were plated onto a 96-well plate (1000/well) at days 3 and 7 after seeding. Medium was removed and CCK reagent $(10 \mu \mathrm{L})$ was added to each well and incubated for $1-4 \mathrm{~h}$. To quantify metabolic activity, absorbance was measured at $450 \mathrm{~nm}$ and wells without cells were used as a negative control.

\section{Flow cytometry}

Cells were digested with trypsin-EDTA, washed twice with PBS, centrifuged, resuspended in cold $70 \%$ ethanol, and kept at $4{ }^{\circ} \mathrm{C}$ overnight. Fixed cells were then washed twice with PBS and incubated with RNase at $37^{\circ} \mathrm{C}$ for $30 \mathrm{~min}$ (Thermo Fisher Scientific, AM2269) and propidium iodide for $20 \mathrm{~min}$ (Thermo Fisher Scientific, P3566) in the dark. Absorbance was measured at $488 \mathrm{~nm}$ by flow cytometry (BD, USA, FACSort).

\section{Measurement of nail growth rate}

Study participants were recruited from May 2017 to August 2017. Young participants were 1-2 years old and elderly participants were over 60 years of age. In total, 72 participants were recruited and 64 completed the study (Table 1).
Fig. 2 Expression of stem cell markers and the difference between young and aged participants in human nail stem cells. a Immunohistochemical staining for K14, K15, and K19 in human nails. These three markers were all expressed in the NPF and Mx in both groups. Compared to K14 and K15, the expression of K19 was relatively weak, but there was no significant difference between the two groups (scale bar $=400 \mu \mathrm{m}$ ). b Immunohistochemical staining for CD29, CD34, and Lgr6 in human nails. The markers were expressed in the same area (scale bar $=400 \mu \mathrm{m}$ ). $\mathbf{c}$ Proportion of positive cells stained for K14, K15, K19, CD29, CD34, and Lgr6 in analysed slices $(n=58, p>0.05)$, illustrating no significant difference between the two groups. d Diagrammatic drawing of the nail root. The area in the blue and black box was used to determine the percentage of positive cells. e Co-immunofluorescence staining for K14 and K15 (scale bar $=400 \mu \mathrm{m})$. (Color figure online $)$

Exclusion factors included use of nail polish, onychophagia, use of medication, and chronic disease. All participants gave written informed consent, and the study was approved by the Ethics Committee at Huazhong University of Science and Technology. Participants were provided with a flexible ruler, a nail file, standardised forms for recording the measurements, and a study protocol. Nail length was measured according to Dawbe (Dawber 1970). At baseline, we marked the participants' fingernails near the proximal nail fold by using a nail file with moderate weight. We recorded the first and last date and the distance in millimeters from the proximal nail fold to the mark at two different time points. Participants were free to clip their nails, and nail clipping of infants was performed by a guardian. The nail growth rate was obtained by taking the difference in recorded distance from the proximal nail fold and dividing by the number of days between the two measurements (Yaemsiri et al. 2010).
Table 1 Characteristics of participants

\begin{tabular}{lll}
\hline Characteristics & $\begin{array}{l}\text { Participants of slice specimens } \\
(\mathrm{n}=58)\end{array}$ & $\begin{array}{l}\text { Participants of } \\
\text { nail grow rate } \\
(\mathrm{n}=64) \\
\mathrm{n}(\%)\end{array}$ \\
\hline Female & $\mathrm{n}(\%)$ & $46(71.9)$ \\
Age group (years) & $22(37.9)$ & $34(53.1)$ \\
$1-3$ & $34(58.6)$ & $30(46.9)$ \\
$60-70$ & $24(41.4)$ & $3(4.7)$ \\
Body mass index $\left(\mathrm{kg} / \mathrm{m}^{2}\right)$ & & $54(84.4)$ \\
$<18.5$ & $3(5.2)$ & $7(10.9)$ \\
$18.5-24$ & $49(84.5)$ & $0(0)$ \\
$24-28$ & $6(10.3)$ & $59(92.2)$ \\
$\geq 30$ & $0(0)$ & $0(0)$ \\
Dominant right hand & $52(89.7)$ & $0(0)$ \\
Any onychophagia & $0(0)$ & $0(0)$ \\
Medication used in past year & $0(0)$ & $0(0)$ \\
Nail polished & $0(0)$ & $12(18.8)$ \\
Any chronic disease & $3(5.2)$ &
\end{tabular}



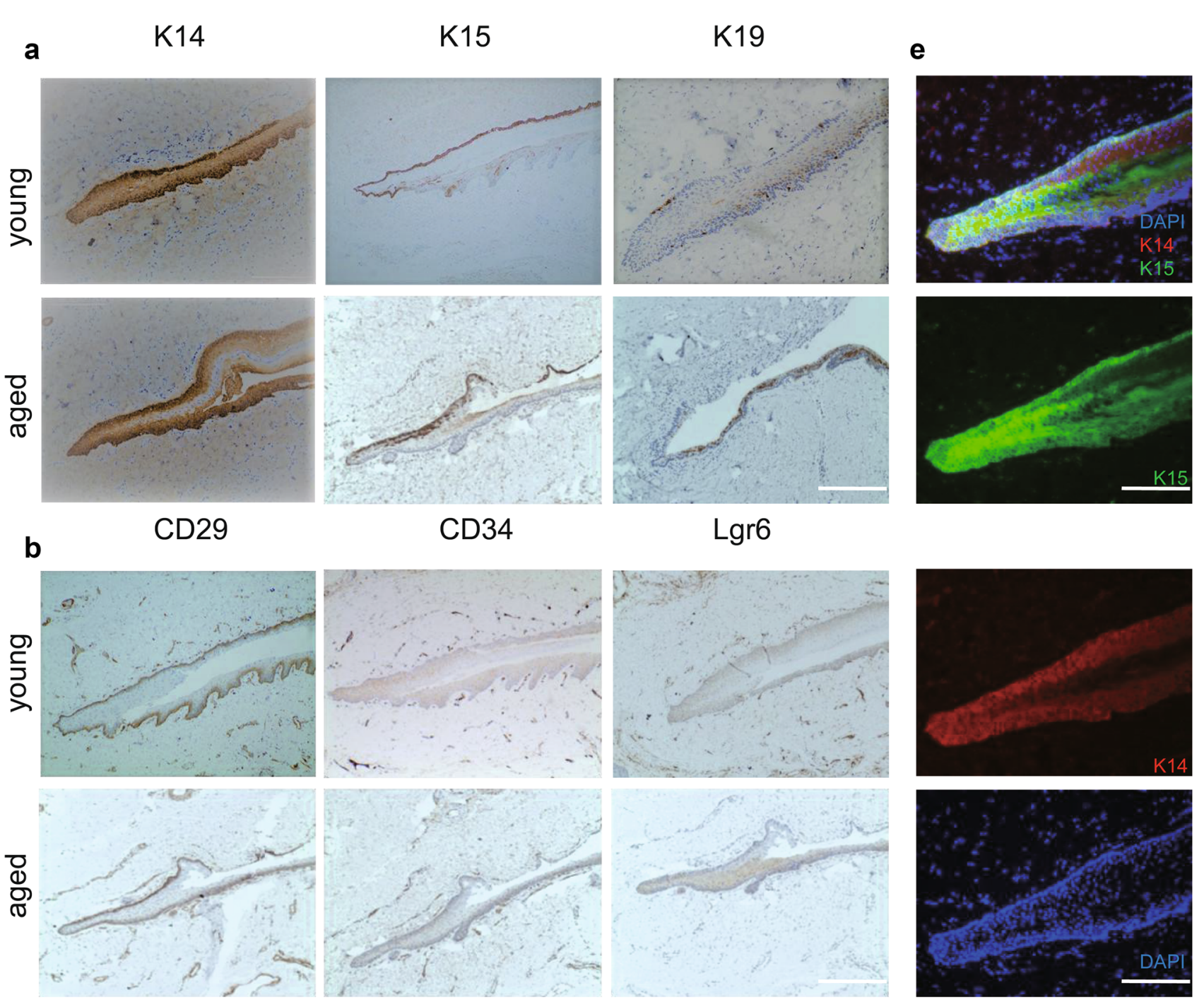

CD34

Lgr6
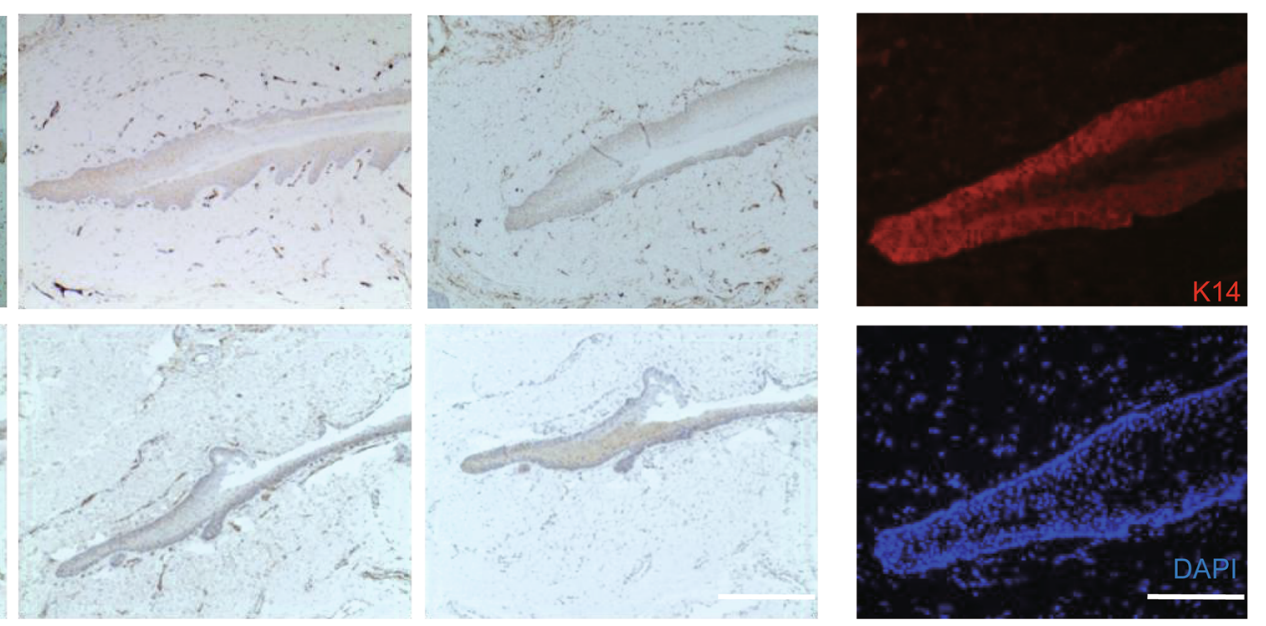

c

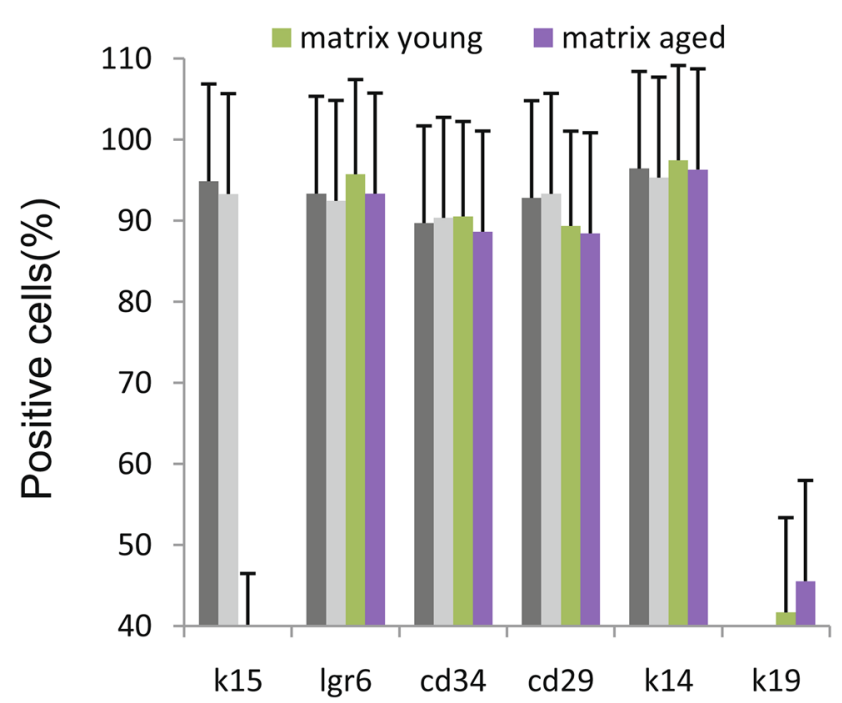

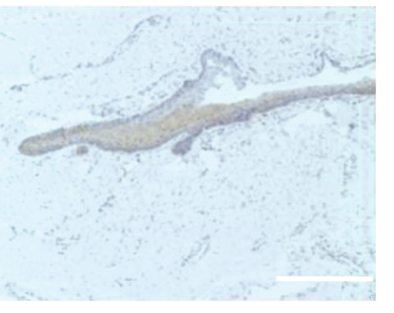

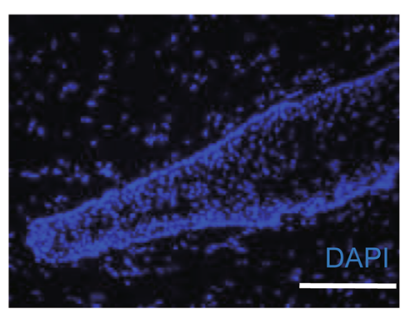

d

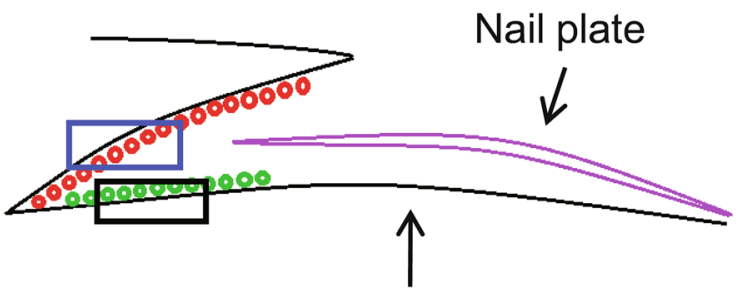

Nail bed

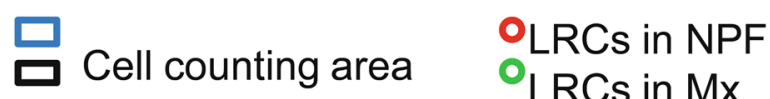


We compared the left and right nail growth rates and tested whether there were significant differences using paired $t$ tests. We also compared mean nail growth rates and the growth rate of each fingernail in the young and old groups using paired $t$ tests.

\section{Statistical analysis}

Experiments were performed three times with similar results. All data are given as the mean $\pm 95 \%$ confidence intervals. The $t$ test was used to compare the differences between the two groups. Statistical significance was defined as $p<0.05$.

\section{Results}

\section{Identification of human nail stem cells ex vivo}

To locate and identify human nail stem cells, we used extracorporeal specimens from children with polydactyly and severed fingers from adults with trauma leading to amputation (Fig. 1a). H\&E staining revealed the morphology of the human nail root (Fig. 1b). We detected the expression of stem cell markers around the nails and used Ki67 as a cellular marker for proliferation (Fig. 1d). We observed strong K15 expression (Fig. 1c-f), which was also apparent in epidermal, sweat gland and hair follicle stem cells (Bose et al. 2013; Leung et al. 2013; Takeo et al. 2013). Through the comparison of the photographs with multiple magnifications, we could easily found that those $\mathrm{K} 5^{+}$cells were located at the basal layer. Specifically, $\mathrm{K} 15^{+}$cells are located at both the NPF above the nail plate and proximal to the nail matrix. This result not only differed from Leung et al.'s (2014) reports who only found nail stem cells just at the proximal nail fold, but also other reports that identified nail stem cells only in the nail matrix (Lehoczky and Tabin 2015; Nakamura and Ishikawa 2008; Takeo et al. 2013). To ensure that this result was not a coincidence, we treated 58 human specimens following the same steps and obtained similar results.

\section{High expression of K14, K15, K19, CD29, CD34, and Lgr6 in human nail stem cells and cell abundance are unaffected during aging}

To determine whether stem cells exist in human nails, we investigated multiple biological markers (K14, K15, K19, CD29, CD34, and Lgr6) of skin stem cells in nailsurrounding tissues. The expression of K14, K15, and K19 has been identified in different types of skin stem cells
Fig. 3 Comparison of cell number and fluorescence intensity between the young and aged groups. $\mathbf{a}-\mathbf{j} H \& E$ staining of specimens from the young group (a) and the aged group (b). Immunohistochemical staining for K15 in the two groups: c, d K15 (red); e, f K15 (red), DAPI (blue); g, h K15 (green); i, j K15 (green), DAPI (blue), and Ki67 (red) (scale bar $=200 \mu \mathrm{m}$ ). (k) Cell counting in the same area in the high-power microscope. The aged group had a higher total cell number and K15-positive cell number as compared to the young group $(\mathrm{n}=58, \mathrm{p}<0.01)$. $\mathbf{l}$ The proportion of K15-positive cells was around $90 \%$ in both groups, with no significant difference $(n=58, p=0.5)$, consistent with the immunohistochemical results. m Comparison of fluorescence intensity showed that the young group had significantly higher expression of K15 than the aged group $(n=58, p=0.003)$, as analysed by Image $\mathrm{J} . * * \mathrm{P}<0.01$. (Color figure online)

(Bose et al. 2013; Driskell et al. 2015; Garcin et al. 2016; Leung et al. 2013; Morris et al. 2004; Troy and Turksen 1999; Wang et al. 2012; Zgheib et al. 2015; Zhang et al. 2012). CD29 is the most widely accepted of the skin stem cell markers identified (Bose et al. 2013; Watt 1998). $\mathrm{CD}^{+} 4^{+}$cells are a rich population of skin epithelial stem cells (Hong et al. 2014; Lin et al. 2015; Najafzadeh et al. 2015; Ouji et al. 2015; Zhu et al. 2013). The expression of Lgr6 has been observed in several adult skin stem cells (Barker et al. 2013; Lehoczky and Tabin 2015; Snippert et al. 2010). In human nails, we detected the expression of those six markers in both proximal fold cells and proximal nail matrix cells in all specimens (Fig. 2 a, b), and the expressing regions overlapped, proving the existence of putative human nail stem cells in NPFs and the nail matrix. To analyse the difference between cell numbers in young and aged specimens, we chose the same area of the NPF (Fig. 2d) in each group to count and analyse the cell number $(n=58, p>0.05$, Fig. $2 c)$. We found no significant difference in the proportion of positive cells in each indicator between the young and aged, which indicated that the relative amount of the putative nail stem cells does not change significantly with age. To demonstrate that there is only one putative population of stem cells in human nails, we have performed co-immunofluorescence for K14 and K15 (Fig. 2e). We could see that the cells colored by K14 and K15 were almost completely coincident.

\section{Immunofluorescence intensity of nail stem cell markers and cell proliferation decrease in an age-dependent and stem cell-independent manner}

To determine whether the amount of those cells varies by age, we performed $\mathrm{H} \& \mathrm{E}$ and immunofluorescence staining for Ki67 and K15 in young and aged nail specimens (Fig. 3a-j). Through H\&E staining, we discovered that the absolute number of cells, including the putative nail stem cells and other cells in the epidermis, was increased in aged 


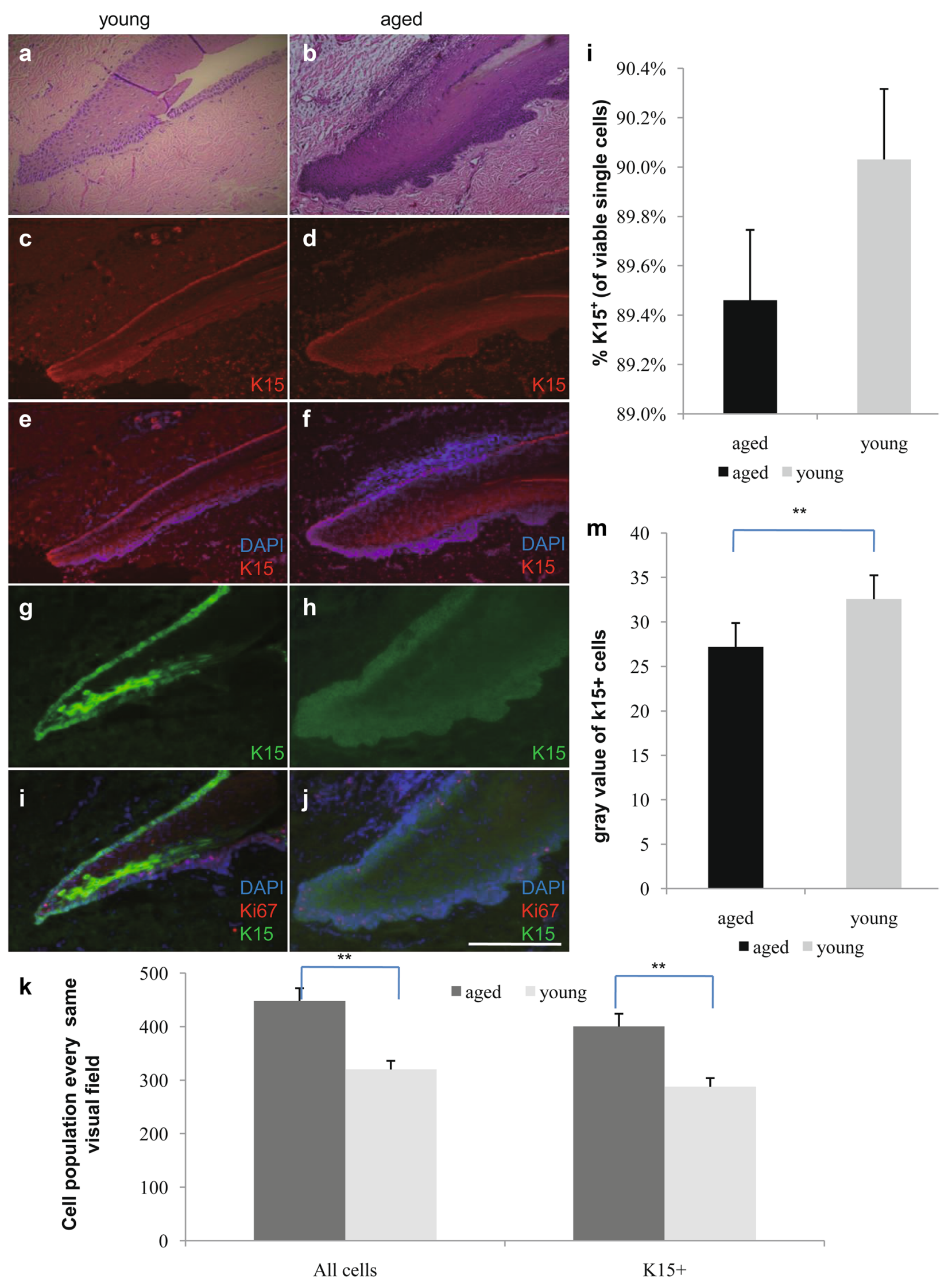



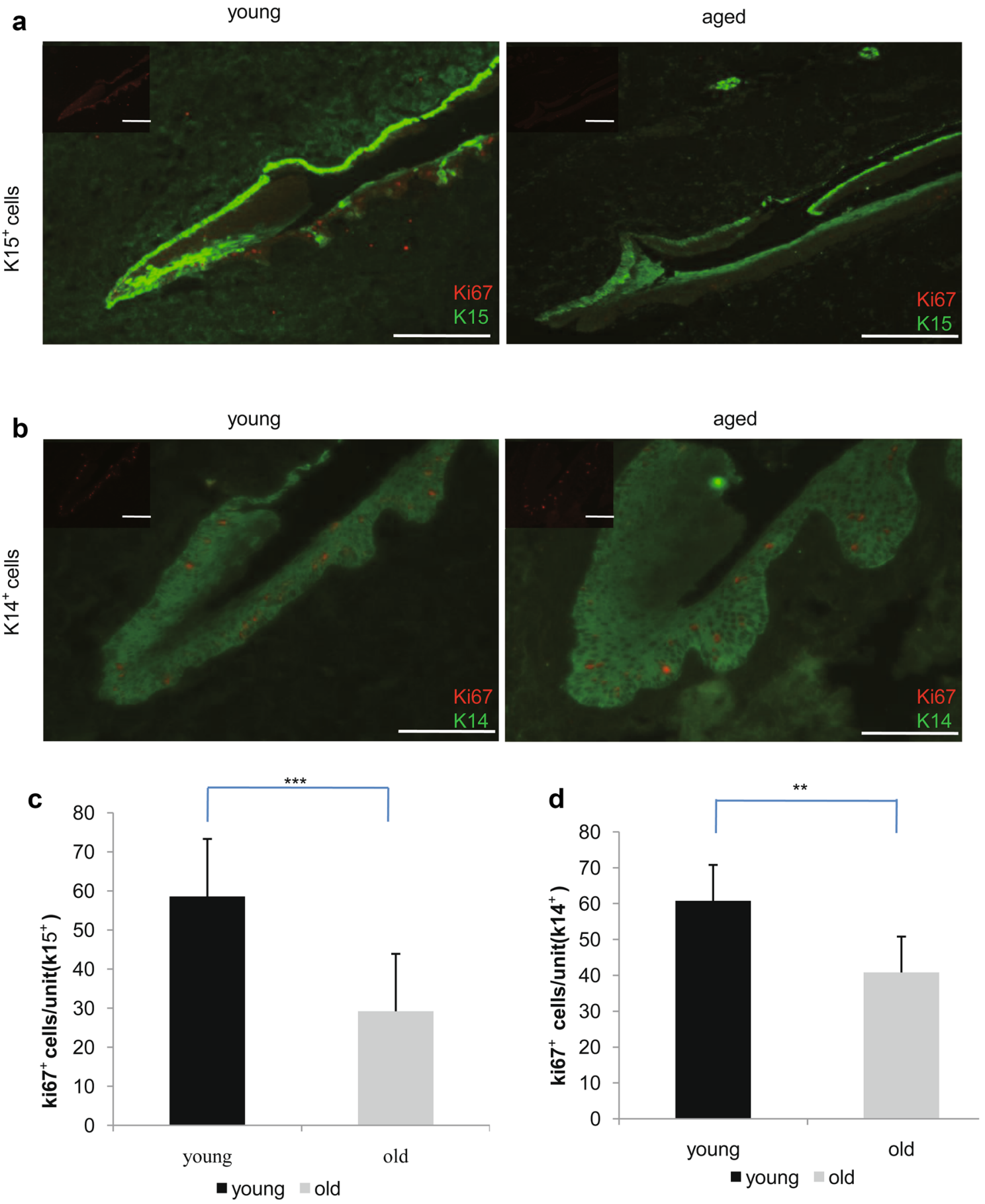

Fig. 4 Comparison of cell proliferation between the young and aged groups. a Comparison of Ki67-positive cells with K15 positivity in the two groups (scale bar $=200 \mu \mathrm{m}$ ), image of separately staining of Ki67 in the upper left corner. c Ki67-positive cell count results; the young group was higher than the aged group $(n=58, p=0.0005)$. $\mathbf{b}$,

samples ( $\mathrm{n}=58, \mathrm{p}<0.01$, Fig. 3a, b, k). However, the fluorescence intensity of stem cells in aged nails was weaker than that observed in young nails. We also stained for K15 in the putative nail stem cells with different fluorescent tags d Comparison of Ki67-positive cells with K14 positivity in the two groups and Ki67-positive cell count results (scale bar $=200 \mu \mathrm{m}$ ), image of separately staining of Ki67 in the upper left corner. Similar results were obtained for both K14 and K15 staining $(\mathrm{n}=58$, $\mathrm{p}=0.002) . * * \mathrm{P}<0.01 * * * \mathrm{P}<0.001$

(Fig. $3 \mathrm{c}-\mathrm{j}$ ) and the results were the same. The percentage of $\mathrm{K} 15^{+}$cells did not differ significantly between young and aged participants $(n=58, p=0.5$, Fig. 31$)$, but the gray value was higher in the young group than in the aged 
group ( $n=58, p=0.003$, Fig. $3 m)$. These results suggest functional differences between young and aged nail stem cells. To confirm this result, we performed immunostaining for Ki67 and K15 (Fig. 4a). Proliferation of the nail root appeared to be decreased in all aged nail samples $(n=58$, $\mathrm{p}=0.0005$, Fig. $4 \mathrm{c}$ ). Labeling for Ki67 also revealed some differences in $\mathrm{K}_{14}{ }^{+}$cell proliferation between young and aged samples $(n=58, p=0.002$, Fig. $4 b, d)$. By selection for nail stem cells, we were able to isolate $\mathrm{K}_{1} 4^{+}$and $\mathrm{K} 15^{+}$ cells (Fig. 5e-h), which exhibited high proliferation capacity (Fig. 5a-d), but showed a difference between young and aged cells (Fig. 5i). To evaluate their proliferation capacity and metabolic activity, we performed CCK8 metabolic assays (Fig. 5j). Flow cytometry also revealed an increase in G1 phase cells concomitant with reductions in S and G2/M phase cells in aged nails (total or $\mathrm{K} 15^{+}$cells; Fig. $5 \mathrm{k}-\mathrm{m}$ ), consistent with a modest decrease in proliferation with age. In addition, we observed a striking difference in colonyforming ability of young and aged $\mathrm{K}^{+} 5^{+}$cells cultured in identical conditions ( $p=0.02$, Fig. 6a, b).

\section{Nails grow slower in aged versus young people}

The nail plate is the product of nail matrix cells (Haneke 2015). However, it is unclear whether nail growth rate and nail stem cell proliferation are related. To determine whether nail proliferation is altered in aged people, we evaluated nail growth in 64 healthy people. Nail growth was significantly higher in the thumb compared to other digits and was slowest in the pinky finger. There were no differences in nail growth between the left and right hands. These results are consistent with previous studies (Buzalaf et al. 2006; Lavelle 1968; Orentreich et al. 1979; Yaemsiri et al. 2010). We also found that the nail growth rate in aged participants was significantly slower than in young participants, in each finger $(n=64, p=0.03$, Fig. 6c). In two cases, the nail growth rate in the right thumb was not faster than the other digits. Both of these cases were dominant in the right hand; therefore, this result may be due to wear or inhibition of growth caused by labor. The formation of nails is initiated in the area containing nail stem cells (Haneke 2015), and the nail growth rate is consistent with stem cell function based on our research. Additionally, Leung verified that NPF stem cells actively participate in nail regeneration in mice (Leung et al. 2014). Therefore, there are reasons to believe that there is a link between stem cells and nail growth, and the active proliferation of stem cells may lead to formation of the nail plate, which induces nail growth. However, further research is needed to prove this hypothesis.

\section{Discussion}

Stem cells are defined as cells with an extensive capacity for self-renewal and the ability to generate differentiated daughter cells (Watt and Driskell 2010). Almost all stem cells have special cell markers, and the locations of stem cells are relatively constant. Researchers have previously used label-retaining cells to identify stem cells in mouse nails (Lehoczky and Tabin 2015; Leung et al. 2014; Nakamura and Ishikawa 2008; Takeo et al. 2013). Although some scholars have defined nail stem cells using embryonic nails (Sellheyer and Nelson 2012), the existence of stem cells in postnatal human nails, which are continuously growing, has not yet been determined. This is, therefore, the first article to explore human nail stem cells.

Although many previous studies have observed stem cells in mouse nails, their results differed in terms of the location of the mouse nail stem cells. Leung et al. identified nail stem cells in the NPF (Leung et al. 2014). However, some studies reported that stem cells were found in the nail matrix (Lehoczky and Tabin 2015; Nakamura and Ishikawa 2008; Takeo et al. 2013). These discrepancies may have arisen because of differences in the experimental markers, methods, and/or time periods used in each study. In view of these differences, we used the same experimental methods to test the recognised stem cell markers. We observed multiexpressing cells within the NPF and nail matrix (Fig. 2a, b). We believe that the cells we observed in human nails are the same as those cells found in mice (Lehoczky and Tabin 2015; Leung et al. 2014), which have been determined to promote digit tip regeneration.

Leung et al. demonstrated that mouse NPF stem cells express $\mathrm{K} 15$ and that these cells not only contribute to nail structure but also to the peri-nail epidermis (Leung et al. 2014). When nails suffer injury, nail stem cells can respond rapidly, activate, and allow the nail matrix to take part in differentiation of the nail plate during regeneration (Leung et al. 2014). K15 expression has been identified in a number of adult epidermal stem cells (Garcin et al. 2016; Leung et al. 2013; Lin et al. 2015). K14 and K19 have been confirmed to be expressed in skin stem cells (Driskell et al. 2015; Zhang et al. 2012). In our study, K14 and K19 were expressed in the same cells as K15. This reinforces the fact that the $\mathrm{K} 15^{+}$cells we found in human nails are likely to be one type of stem cell (i.e., nail stem cells). However, in later research, Lehoczky et al. revealed that Lgr6-expressing cells generate the nail plate. As previously characterised, Lgr6 ${ }^{+}$ cells contribute to the growth of hair follicles and sebaceous gland structures and can differentiate into all cell lines in the skin (Snippert et al. 2010). Lgr6-GFP expression has been observed in the digit tips, particularly in the nail matrix (Lehoczky and Tabin 2015). Therefore, we chose Lgr6 as a 

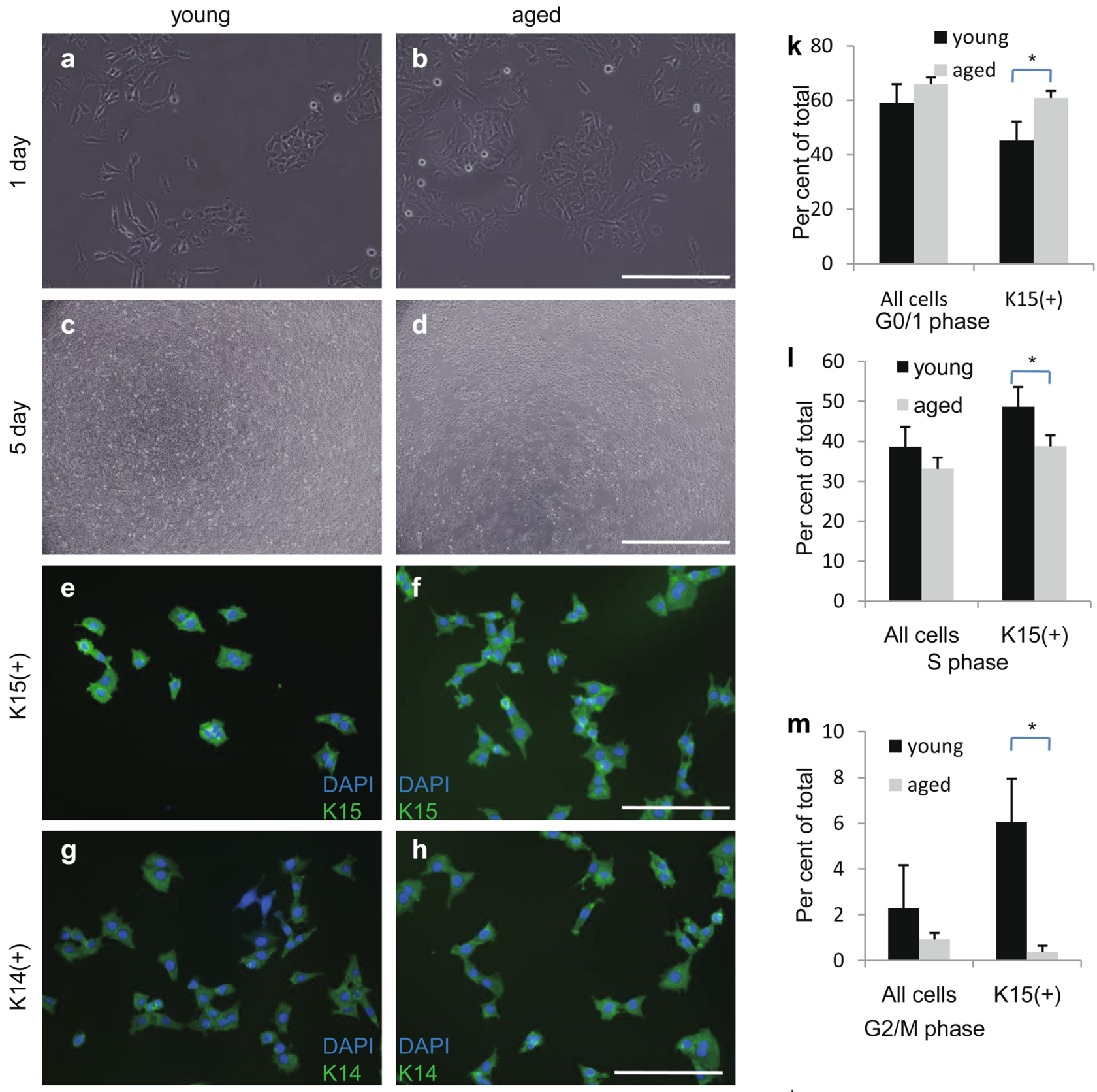

All cells $\mathrm{K} 15(+)$

G0/1 phase
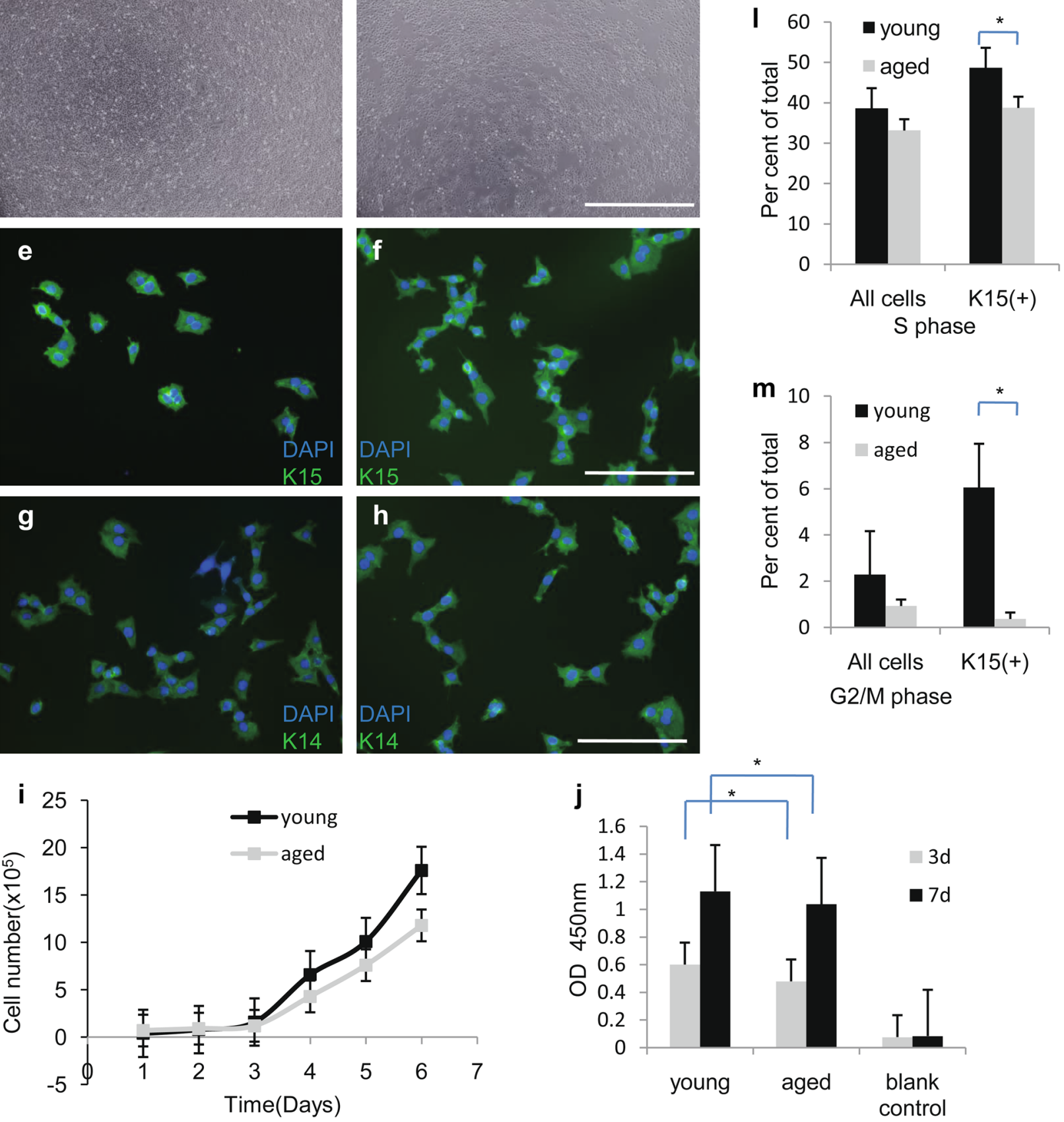
4Fig. 5 Comparison of nail stem cell proliferation and viability between the young and aged groups. $\mathbf{a}-\mathbf{h}, \mathbf{i}$ Nail stem cell characterisation. When cultured in DKSFM, the cells tended to clump together (a, b; scale bar $=1000 \mu \mathrm{m}$ ) and showed high proliferation capacity (c, d, i; scale bar $=200 \mu \mathrm{m})$. e-h Immunofluorescence staining for K14, K15 (green), and cell nuclei (DAPI/blue) (scale bar $=200 \mu \mathrm{m}$ ). j After seeding, cell viability was evaluated by CCK assays; the cell metabolic activity of the young group was significantly higher than the aged group $(\mathrm{p}=0.04)$. $\mathbf{k}-\mathbf{m}$ Flow cytometric analysis of total (left side graphs) or $\mathrm{K} 15(+)$ (right side graphs) cell cycle status in young versus old nail preparations $(\mathrm{p}<0.05)$. $* \mathrm{P}<0.05$. (Color figure online)

marker for all specimen slices. We subsequently identified Lgr6 expression in $\mathrm{K} 15^{+}$cells. CD34 and CD29 are generally recognised as commonly occurring in skin epithelial stem cells and are widely accepted as stem cell markers (Bose et al. 2013; Hong et al. 2014; Najafzadeh et al. 2015; Ouji et al. 2015; Watt 1998; Zhu et al. 2013). Additionally, their expression has been discovered in the same cells in human nails (Fig. 2a, b). Sellheyer et al. reported that, during embryo formation, the expression of hair follicle stem cell markers was found in the NPF (Sellheyer and Nelson 2012), suggesting a nail stem cell niche in human adults that does not disappear with maturation of the embryo.

We performed statistical analysis on stem cell numbers in young and aged specimens, and found no significant difference in terms of the quantitative proportion of cells between the two groups. This trend has been confirmed in other skin stem cells, such as hair follicle stem cells (Giangreco et al. 2008; Keyes et al. 2013; Schultz and Sinclair 2016). Although some researchers detected decreased expression of mesenchymal stem cell markers in components of the human umbilical cord, as well as a trend for age-related changes of stem cell markers, we were unable to find many studies that illustrate the change of stem cell numbers with age (Alrefaei et al. 2015; Cuevas-Diaz Duran et al. 2013). Instead, regarding skin stem cells, some studies have found that the number of stem cells increases or does not vary with age (Keyes et al. 2013; Schultz and Sinclair 2016). Other stem cells have been demonstrated to increase in number but decrease in functional capacity with aging (Rossi et al. 2005), further proving that the cells we found share common features with other adult stem cells, not only skin stem cells. We simultaneously used immunohistochemistry and immunofluorescence to count the number of the putative nail stem cells, which revealed the same outcome: an increased total number of cells and an unchanged proportion of nail stem cells. However, immunofluorescence revealed another phenomenon: the fluorescence intensity decreased in the case of aged nail staining, suggesting changes with aging, which contribute to the decline of nail stem cell activity. Nail stem cells from aged nails were present in equivalent numbers in the young. Therefore, the changes in activity were not based in a decline in the nail stem cell pool. We also found that $\mathrm{K} 15^{+}$cells from young nails exhibited stronger proliferation ability than aged nails, suggesting that these cells retain stem-like properties during aging. In addition, the nail growth rate in aged nails was slower than that in young nails. Thus, since the nail plate is the product of nail matrix cells (Haneke 2015), the deceleration in growth rate is likely to be the result of reduced stem cell activity. This result also confirms the existence of the putative nail stem cells.

One limitation of our research is that we did not have enough samples to successfully explore the stem properties of the cells we researched, which was the major cause of insufficient evidence of nail stem cells, which will be the focus of our next work.

To our knowledge, human limbs cannot fully regenerate after amputation unless they undergo replantation, in which case the aim is to keep as much of the normal length as possible. However, when the condition of the residual limb is unsatisfactory, even replantation cannot maintain a normal length. There have been reports that fingertips could regrow in mice and children after guillotine amputation distal to the last interphalangeal joint (Borgens 1982; Douglas 1972). We found the putative nail stem cells, which express several stem cell markers, do not decrease or disappear with aging in human nails. If self-rehabilitation can be initiated by those cells, novel therapeutics could be developed for the treatment of digit defects and amputation.

\section{Conclusions}

Our data suggest that stem cells exist in human nails. These cells express multi-stem cell markers during the whole life, but they are hypofunctional during aging. 


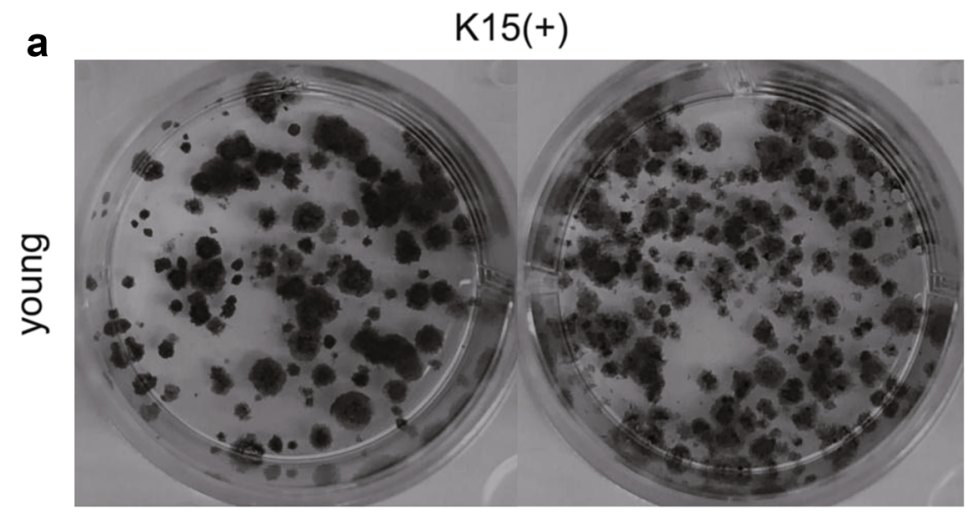

b

Colony number
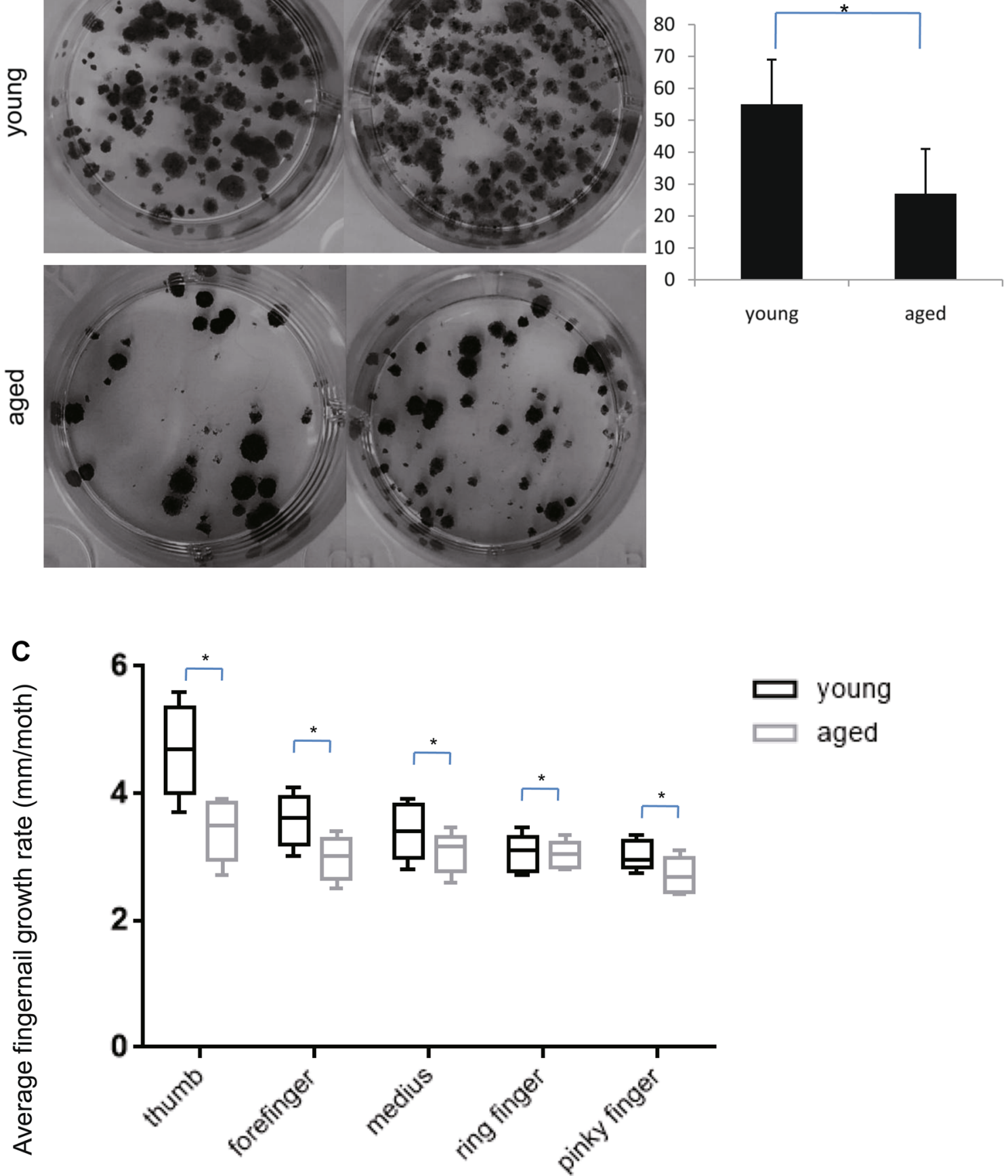

Fig. 6 Age-associated hypofunctional in $\mathrm{K} 15^{+}$cells and nail growth rate. a Colony-forming assays of $\mathrm{K} 15^{+}$cells from young and aged nails. $\mathbf{b}$ Quantification of colony number $(\mathrm{p}=0.02)$. $\mathbf{c}$ Comparison of average fingernail growth rates between the young and aged groups.

Acknowledgements The authors thank our research assistant Peng Cheng, Libo Zhao, Wei Wu, Mi Li, Ye Ren, and Yong Li for providing the samples. The authors also thank Huiyong Liu for the guidance and help in the late-stage study. This research was supported by
Nails grew more slowly in the aged group compared to the young group $(n=64, p=0.03)$. Average nail growth rates are presented in mm per month (defined as 30 days). Bars represent $95 \%$ confidence intervals. $* \mathrm{P}<0.05$

Grants from the National Nature Science Foundation of China (No. 81472106). 
Author contributions HK: Conception and design, financial support,administrative support, final approval of manuscript. ZZ: Provision of study material or patients, guidance on the manuscript. JS: Collection and/or assembly of data,data analysis and interpretation,manuscript writing conducted the main experiments. ZL: guidance on the manuscript. MN: Provision of study material or patients. WL: Provision of study material or patients. CL: Collection of samples. YT: Collection of samples. LL: Data analysis and interpretation. GZ: Data analysis and interpretation. RR: Data analysis and interpretation.

\section{Compliance with ethical standards}

Conflict of interest All authors declare that they have no conflicts of interest.

Open Access This article is distributed under the terms of the Creative Commons Attribution 4.0 International License (http://creativeco mmons.org/licenses/by/4.0/), which permits unrestricted use, distribution, and reproduction in any medium, provided you give appropriate credit to the original author(s) and the source, provide a link to the Creative Commons license, and indicate if changes were made.

\section{References}

Alrefaei GI, Ayuob NN, Ali SS, Al-Karim S (2015) Effects of maternal age on the expression of mesenchymal stem cell markers in the components of human umbilical cord. Folia Histochem Cytobiol 53:259-271. https://doi.org/10.5603/FHC.a2015.0022

Barker N, Tan S, Clevers H (2013) Lgr proteins in epithelial stem. Cell Biol Dev 140:2484-2494. https://doi.org/10.1242/dev.083113

Borgens RB (1982) Mice regrow the tips of their foretoes. Science 217:747-750

Bose A, Teh MT, Mackenzie IC, Waseem A (2013) Keratin k15 as a biomarker of epidermal stem cells. Int J Mol Sci 14:1938519398. https://doi.org/10.3390/ijms 141019385

Buzalaf MA, Pessan JP, Alves KM (2006) Influence of growth rate and length on fluoride detection in human nails. Caries Res 40:231238. https://doi.org/10.1159/000092231

Cotsarelis G (2006) Gene expression profiling gets to the root of human hair follicle stem cells. J Clin Investig 116:19-22. https://doi. org/10.1172/JCI27490

Cuevas-Diaz Duran R, Gonzalez-Garza MT, Cardenas-Lopez A, Chavez-Castilla L, Cruz-Vega DE, Moreno-Cuevas JE (2013) Age-related yield of adipose-derived stem cells bearing the lowaffinity nerve growth factor receptor. Stem Cells Int 2013:372164. https://doi.org/10.1155/2013/372164

Danner S et al (2012) The use of human sweat gland-derived stem cells for enhancing vascularization during dermal regeneration. J Investig Dermatol 132:1707-1716. https://doi.org/10.1038/jid.2012.31

Dawber R (1970) Fingernail growth in normal and psoriatic subjects. Br J Dermatol 82:454-457

Douglas BS (1972) Conservative management of guillotine amputation of the finger in children. Aust Paediatr J 8:86-89

Driskell I, Oeztuerk-Winder F, Humphreys P, Frye M (2015) Genetically induced cell death in bulge stem cells reveals their redundancy for hair and epidermal regeneration. Stem cells 33:988-998. https://doi.org/10.1002/stem.1910

Egana JT, Fierro FA, Kruger S, Bornhauser M, Huss R, Lavandero S, Machens HG (2009) Use of human mesenchymal cells to improve vascularization in a mouse model for scaffold-based dermal regeneration. Tissue Eng A 15:1191-1200. https://doi. org/10.1089/ten.tea.2008.0097

Garcin CL, Ansell DM, Headon DJ, Paus R, Hardman MJ (2016) Hair follicle bulge stem cells appear dispensable for the acute phase of wound re-epithelialization. Stem Cells 34:1377-1385. https:// doi.org/10.1002/stem.2289

Giangreco A, Qin M, Pintar JE, Watt FM (2008) Epidermal stem cells are retained in vivo throughout skin aging. Aging Cell 7:250-259. https://doi.org/10.1111/j.1474-9726.2008.00372.x

Haneke E (2014) Anatomy, biology, physiology and basic pathology of the nail organ (Der Hautarzt; Zeitschrift fur Dermatologie). Venerol verwandte Gebiete 65:282-290. https://doi.org/10.1007/ s00105-013-2702-2

Haneke E (2015) Anatomy of the nail unit and the nail biopsy. In: Seminars in cutaneous medicine and surgery. Frontline Med Commun 34:95-100. https://doi.org/10.12788/j.sder.2015.0143

Hong S, Alapure BV, Lu Y, Tian H, Wang Q (2014) Immunohistological localization of endogenous unlabeled stem cells in wounded skin. J Histochem Cytochem 62:276-285. https://doi. org/10.1369/0022155414520710

Johansen C (2017) Generation and culturing of primary human keratinocytes from adult skin. JoVE. https://doi. org/10.3791/56863

Jones PH, Watt FM (1993) Separation of human epidermal stem cells from transit amplifying cells on the basis of differences in integrin function and expression. Cell 73:713-724

Keyes BE et al (2013) Nfatc1 orchestrates aging in hair follicle stem cells. Proc Natl Acad Sci USA 110:E4950-E4959. https://doi. org/10.1073/pnas.1320301110

Lavelle C (1968) The effect of age on the rate of nail growth. J Gerontol 23:557-559

Lehoczky JA, Tabin CJ (2015) Lgr6 marks nail stem cells and is required for digit tip regeneration. Proc Natl Acad Sci USA 112:13249-13254. https://doi.org/10.1073/pnas.1518874112

Leung Y, Kandyba E, Chen YB, Ruffins S, Kobielak K (2013) Label retaining cells (LRCs) with myoepithelial characteristic from the proximal acinar region define stem cells in the sweat gland. PLoS ONE 8:e74174. https://doi.org/10.1371/journal.pone.0074174

Leung Y, Kandyba E, Chen YB, Ruffins S, Chuong CM, Kobielak K (2014) Bifunctional ectodermal stem cells around the nail display dual fate homeostasis and adaptive wounding response toward nail regeneration. Proc Natl Acad Sci USA 111:15114-15119. https:// doi.org/10.1073/pnas.1318848111

Li A, Simmons PJ, Kaur P (1998) Identification and isolation of candidate human keratinocyte stem cells based on cell surface phenotype. Proc Natl Acad Sci USA 95:3902-3907

Lin CM et al (2015) Expression of Wnt/beta-catenin signaling, stemcell markers and proliferating cell markers in rat whisker hair follicles. J Mol Histol 46:233-240. https://doi.org/10.1007/s1073 5-015-9616-5

Lyle S, Christofidou-Solomidou M, Liu Y, Elder DE, Albelda S, Cotsarelis G (1998) The C8/144B monoclonal antibody recognizes cytokeratin 15 and defines the location of human hair follicle stem cells. J Cell Sci 111(Pt 21):3179-3188

Mackenzie IC (1970) Relationship between mitosis and the ordered structure of the stratum corneum in mouse epidermis. Nature 226:653-655

Mackenzie IC (1997) Retroviral transduction of murine epidermal stem cells demonstrates clonal units of epidermal structure. J Investig Dermatol 109:377-383

Morris RJ et al (2004) Capturing and profiling adult hair follicle stem cells. Nat Biotechnol 22:411-417. https://doi.org/10.1038/nbt950

Najafzadeh N, Sagha M, Heydari Tajaddod S, Golmohammadi MG, Massahi Oskoui N, Deldadeh Moghaddam M (2015) In vitro neural differentiation of CD34 (+) stem cell populations in hair follicles by three different neural induction protocols. In vitro 
Cell Dev Biol Anim 51:192-203. https://doi.org/10.1007/s1162 6-014-9818-2

Nakamura M, Ishikawa O (2008) The localization of label-retaining cells in mouse nails. J Investig Dermatol 128:728-730. https:// doi.org/10.1038/sj.jid.5701062

Neufeld DA, Zhao W (1995) Bone regrowth after digit tip amputation in mice is equivalent in adults and neonates. Wound Repair Regen 3:461-466. https://doi.org/10.1046/j.1524-475X.1995.30410.x

Nowak JA, Fuchs E (2009) Isolation and culture of epithelial stem cells. Methods Mol Biol 482:215-232. https://doi.org/10.1007/978-159745-060-7_14

Orentreich N, Markofsky J, Vogelman JH (1979) The effect of aging on the rate of linear nail growth. J Investig Dermatol 73:126-130

Oshima H, Rochat A, Kedzia C, Kobayashi K, Barrandon Y (2001) Morphogenesis and renewal of hair follicles from adult multipotent stem cells. Cell 104:233-245

Ouji Y, Ishizaka S, Nakamura-Uchiyama F, Okuzaki D, Yoshikawa M (2015) Partial maintenance and long-term expansion of murine skin epithelial stem cells by Wnt-3a in vitro. J Investig Dermatol 135:1598-1608. https://doi.org/10.1038/jid.2014.510

Rinkevich Y, Lindau P, Ueno H, Longaker MT, Weissman IL (2011) Germ-layer and lineage-restricted stem/progenitors regenerate the mouse digit tip. Nature 476:409-413. https://doi.org/10.1038/ nature 10346

Rossi DJ, Bryder D, Zahn JM, Ahlenius H, Sonu R, Wagers AJ, Weissman IL (2005) Cell intrinsic alterations underlie hematopoietic stem cell aging. Proc Natl Acad Sci USA 102:9194-9199. https ://doi.org/10.1073/pnas.0503280102

Schultz MB, Sinclair DA (2016) When stem cells grow old: phenotypes and mechanisms of stem cell aging. Development 143:3-14. https ://doi.org/10.1242/dev.130633

Sellheyer K, Nelson P (2012) The ventral proximal nail fold: stem cell niche of the nail and equivalent to the follicular bulge - a study on developing human skin. J Cutan Pathol 39:835-843. https:// doi.org/10.1111/j.1600-0560.2012.01949.x

Snippert HJ et al (2010) Lgr6 marks stem cells in the hair follicle that generate all cell lineages of the skin. Science 327:1385-1389. https://doi.org/10.1126/science. 1184733

Takeo M et al (2013) Wnt activation in nail epithelium couples nail growth to digit regeneration. Nature 499:228-232. https://doi. org/10.1038/nature12214

Toma JG, Akhavan M, Fernandes KJ, Barnabe-Heider F, Sadikot A, Kaplan DR, Miller FD (2001) Isolation of multipotent adult stem cells from the dermis of mammalian skin. Nat Cell Biol 3:778784. https://doi.org/10.1038/ncb0901-778
Trempus CS, Morris RJ, Bortner CD, Cotsarelis G, Faircloth RS, Reece JM, Tennant RW (2003) Enrichment for living murine keratinocytes from the hair follicle bulge with the cell surface marker CD34. J Investig Dermatol 120:501-511. https://doi.org/10.104 6/j.1523-1747.2003.12088.x

Troy TC, Turksen K (1999) In vitro characteristics of early epidermal progenitors isolated from keratin 14 (K14)-deficient mice: insights into the role of keratin 17 in mouse keratinocytes J Cell Physiol 180:409-421. https://doi.org/10.1002/(SICI)1097-4652(19990 9)180:3\%3C409::AID-JCP12\%3E3.0.CO;2-V

Wang X, Shi Y, Zhou Q, Liu X, Xu S, Lei T (2012) Detailed histological structure of human hair follicle bulge region at different ages: a visible niche for nesting adult stem cells. J Huazhong Univ Sci Technol Med Sci 32:648-656. https://doi.org/10.1007/s1159 6-012-1012-8

Watt FM (1998) Epidermal stem cells: markers, patterning and the control of stem cell fate. Philos Trans R Soc Lond Ser B 353:831837. https://doi.org/10.1098/rstb.1998.0247

Watt FM, Driskell RR (2010) The therapeutic potential of stem cells. Philos Trans R Soc Lond Ser B 365:155-163. https://doi. org/10.1098/rstb.2009.0149

Yaemsiri S, Hou N, Slining MM, He K (2010) Growth rate of human fingernails and toenails in healthy American young adults. JEADV 24:420-423. https://doi.org/10.1111/j.1468-3083.2009.03426.x

Zaias N (1963) Embryology of the human nail. Arch Dermatol $87: 37-53$

Zgheib C, Xu J, Mallette AC, Caskey RC, Zhang L, Hu J, Liechty KW (2015) SCF increases in utero-labeled stem cells migration and improves wound healing. Wound Repair Regen 23:583-590. https ://doi.org/10.1111/wrr.12318

Zhang S et al (2012) Hair follicle stem cells derived from single rat vibrissa via organ culture reconstitute hair follicles in vivo. Cell Transplant 21:1075-1085. https://doi.org/10.3727/096368912X 640538

Zhu B, Smith J, Yarmush ML, Nahmias Y, Kirby BJ, Murthy SK (2013) Microfluidic enrichment of mouse epidermal stem cells and validation of stem cell proliferation in vitro. Tissue Eng C 19:765-773. https://doi.org/10.1089/ten.TEC.2012.0638

Zhu B, Nahmias Y, Yarmush ML, Murthy SK (2014) Microfluidic isolation of CD34-positive skin cells enables regeneration of hair and sebaceous glands. Vivo Stem Cells Transl Med 3:1354-1362. https://doi.org/10.5966/sctm.2014-0098 